\title{
Minerals Formed by Treatment of Heavy Metals with Orthophosphate, Silica or an Orthophosphate-Silica Mix Treatment under Cold Conditions
}

\author{
Danielle Camenzuli
}

\begin{abstract}
The application of orthophosphate and silica chemical treatments to contaminated land in cold regions remains understudied. The potential of mixed silica-orthophosphate treatments for the management of metal contaminated sites has not been examined. Investigation and characterization of the mineral products which form during treatment, to ensure their suitability and stability for remediation and contaminant migration prevention is essential. This should be achieved prior to in-situ implementation. This paper observes the mineral products formed by reaction between orthophosphate, silica and orthophosphate-silica mix treatment(s) and lead sulfate, copper oxide and zinc oxide systems over 114 days using X-ray diffractometry. Detectable changes to the mineral composition of analyzed specimens occurred in all systems. Immobilization was most effective for lead and least effective for zinc. This study demonstrates the potential of chemical treatments for the management of metal contaminated sites in cold regions. However, the results of this study demonstrate that treatments must be designed with consideration of factors such as environmental risk, the various stabilities of mineral products formed, temperature and the solubility of contaminant phases requiring treatment.
\end{abstract}

Index Terms - Cold regions, heavy metals, immobilization, remediation, stabilization.

\section{INTRODUCTION}

Metal contaminated sites requiring treatment are widespread, even in remote, cold regions [1]-[3]. Managing contaminated land in cold regions is typically confounded by financial and logistical constraints, extreme weather and a lack of clear, governing legislation [1], [3]. Cold regions are also characterized by low primary productivity, slow growth and degradation rates and are often more vulnerable to disturbance [2], [4], [5]. Excavation and subsequent removal of contaminated soil in cold regions is often not possible due to expense and large distances to secure landfills [3], [5]. Furthermore, disturbance to contaminated material can result in the re-mobilization or re-suspension of contaminants. This is particularly relevant to permafrost, where thawing of previously frozen material may enhance metal contaminant solubility and the potential for contaminant migration [5]-[8]. Hence, technologies that can be applied on-site or in-situ are

Manuscript received September 30, 2014; revised March 2, 2015. This work was financially supported in part by Australian Antarctic Science grant no. 4029 and by the Macquarie University Post Graduate Research Award Fund.

D. Camenzuli is with the Department of Environmental Science, Macquarie University, Sydney, NSW, 2109, Australia (e-mail: danielle.camenzuli@mq.edu.au). often preferable when managing contaminated sites in remote, cold regions.

Chemical fixation technologies have been developed for both on-site or in-situ management of contaminated sites, and are widely used in temperate regions [3], [9]-[11]. Chemical fixation treatments immobilize metals and reduce the leachability and mobility of contaminants by converting metal ions into sparingly soluble, non-bioavailable minerals [5], [12].

Several treatments have been developed and successfully applied to metal contaminated sites; for instance, orthophosphate, lime, bentonite, Portland cement and silicates [5], [13]-[16]. Studies reporting on successful immobilization of metals using orthophosphate are abundant and the processes responsible for immobilization are well described [17]. Orthophosphate treatments achieve immobilization by reacting with metal cations, including $\mathrm{Mg}^{2+}, \mathrm{Ca}^{2+}, \mathrm{Fe}^{3+}, \mathrm{Cu}^{2+}, \mathrm{Zn}^{2+}$, and $\mathrm{Pb}^{2+}$, to immobilize metals via precipitation or co-precipitation reactions in order to produce insoluble, metal-phosphate minerals [5], [12], [18]. However, there is a scarcity of research reporting on the successful application of silica treatments to metal contaminated sites [16]. Silica treatments immobilize metals via one of three reactions: i) precipitation or co-precipitation reactions, ii) polymerization of soluble silicates or iii) hydration-dehydration reactions [19]-[22]. Currently there are no published studies reporting on the application of silica or orthophosphate-silica mix treatments to metal contaminated sites in cold regions, and consequently there is insufficient data to support their safe application in areas of freezing ground [16].

To assess the efficacy of silica treatments for the immobilization of metals in cold regions, it is essential to first identify the metal-phosphate and metal-silicate products which form upon treatment and determine whether the formation of these mineral phases is rapid and stable enough to prevent contaminant migration [5]. This study seeks to address this research gap by observing the products formed when orthophosphate, silica and an orthophosphate-silica mix treatments react with metals in-vitro, in chemically simple systems, over 114 days at $2{ }^{\circ} \mathrm{C}$, using $\mathrm{X}$-ray diffractometry (XRD).

\section{Methods}

The experimental design of this study included two components. First, XRD was used to assess the purity of the treatment reagents and the other reactants used to form the three experimental systems; (i) lead sulfate $\left(\mathrm{PbSO}_{4}\right)$, (ii) 
copper oxide $(\mathrm{CuO})$, (iii) zinc oxide $(\mathrm{ZnO})$. Subsequently, products formed by reactions between orthophosphate, silica and a silica-orthophosphate mix treatment(s) and $\mathrm{PbSO}_{4}$, $\mathrm{CuO}$ and $\mathrm{ZnO}$ were observed using $\mathrm{XRD}$, under cold $\left(2{ }^{\circ} \mathrm{C}\right)$ conditions. Reducing the number of reactants meant that less abundant reaction products were more likely to be above detection limits, than if a larger number of phases were present in the specimens prepared and analyzed.

TABLE I: COMPOSITION OF ORTHOPHOSPHATE, SILICA AND SILICA-ORTHOPHOSPHATE MIX TREATMENTS

\begin{tabular}{ccc}
\hline \hline Treatment ID & Treatment composition & Total reagent \\
\hline \multirow{2}{*}{ Orthophosphate } & Triple super phosphate & $1.88 \mathrm{~g}$ \\
& Calcined magnesia & $1.25 \mathrm{~g}$ \\
\hline \multirow{2}{*}{ Silica 1 } & Sodium metasilicate & $1.88 \mathrm{~g}$ \\
& Calcium carbonate & $0.63 \mathrm{~g}$ \\
\hline \multirow{2}{*}{ Silica 2 } & Sodium metasilicate & $1.88 \mathrm{~g}$ \\
& Calcium carbonate & $0.63 \mathrm{~g}$ \\
& Orthophosphoric acid (89\%) & $0.65 \mathrm{~mL}$ \\
\hline \multirow{2}{*}{ Orthophosphate- } & Sodium metasilicate & \multirow{2}{*}{$1.88 \mathrm{~g}$} \\
Silica mix & Triple super phosphate & $1.88 \mathrm{~g}$ \\
& Calcined magnesia & $1.25 \mathrm{~g}$ \\
\hline \hline
\end{tabular}

Specimens were prepared by mixing duplicate $5 \mathrm{~g}$ portions of reagent grade $\mathrm{PbSO}_{4}, \mathrm{CuO}$ and $\mathrm{ZnO}$ powders with orthophosphate, silica and a silica-orthophosphate mix treatment(s) and loading the specimens onto stainless steel sample holders for analysis by XRD $(n=24)$. The compositions of the four treatments applied are presented in Table I.

Prior to the treatments being activated, the powder specimens were analyzed on day 0 as experimental controls and to provide a benchmark for pre and post treatment comparisons $(n=24)$. Once preliminary XRD analyses were completed, reactions were initiated by applying sodium metasilicate dissolved in Type 1 deionized water to the silica treated specimens and Type I water to the orthophosphate and silica-orthophosphate mix treated systems to prompt mineral formation. All reactions were conducted in air, as they would be in the field. Once treated, the loaded specimens were cooled to $2{ }^{\circ} \mathrm{C}$ in a Sanyo 253 incubator, and analyzed 14, 77 and 114 days after treatment using XRD.

Diffractograms from 5 to $90^{\circ} 2 \Theta$ were collected with a PANalytical X'Pert Pro MPD diffractometer, using 45 kV, 40 $\mathrm{mA}, \mathrm{CuK} \alpha$ radiation, $\mathrm{X}^{\prime}$ Celerator detector, Bragg Brentano geometry, and a slew rate of $5^{\circ} 2 \Theta$ per minute. Minerals were identified using PANalytical's Highscore Plus software v2.2.4, with ICDD PDF2 and PAN-ICSD databases.

\section{RESULTS}

XRD analyses undertaken prior to treatment identified anglesite (lead sulfate) as the dominant mineral in all $\mathrm{PbSO}_{4}$ systems. Semi-quantitative XRD analyses on day 0 indicated that the presence of anglesite and periclase $(\mathrm{MgO})$ accounted for $80 \mathrm{wt} \%$ and $20 \mathrm{wt} \%$ of the minerals in $\mathrm{PbSO}_{4}$ systems intended for treatment with orthophosphate or the silica-orthophosphate mix treatment, respectively. Pre-treatment analyses of the systems intended for treatment with either silica 1 or silica 2 were characterized by $70 \mathrm{wt} \%$ anglesite and $30 \mathrm{wt} \%$ calcite (calcium carbonate).

Analyses of $\mathrm{CuO}$ systems on day 0 , before orthophosphate or the silica-orthophosphate mix treatments were activated were characterized as $70 \mathrm{wt} \%$ tenorite (copper oxide), with the remaining $30 \mathrm{wt} \%$ portion consisting of periclase and anhydrite (calcium sulfate). Trace levels of calcite were also detected on day 0 in the $\mathrm{CuO}$ systems intended for treatment with the silica-orthophosphate mix. In $\mathrm{CuO}$ systems treated with silica 1 or silica 2, XRD analyses on day 0 identified the major peaks as tenorite and calcite. Semi-quantitative analyses indicated that tenorite and calcite accounted for 70 $\mathrm{wt} \%$ and $30 \mathrm{wt} \%$ of the specimens, respectively.

TABLE II: Mineral Products Formed uPON REACTIONS WITH ORTHOPHOSPHATE TREATMENTS FOR LEAD SULFATE, COPPER OXIDE AND ZINC OXIDE (MineRAL NAME AND 100\% PEAK LOCATION IN DEGREES $2 \Theta$ IN BRACKETS)

\begin{tabular}{|c|c|c|c|}
\hline Day & $\mathrm{PbSO}_{4}$ & $\mathrm{CuO}$ & $\mathrm{ZnO}$ \\
\hline 0 & $\begin{array}{l}\text {-Lead sulfate (anglesite) }(29.71) \text {. } \\
\text {-Magnesium oxide (periclase) (42.87). }\end{array}$ & $\begin{array}{l}\text {-Copper oxide (tenorite) (35.50). } \\
\text {-Magnesium oxide (periclase) (42.92). } \\
\text {-Calcium sulfate (anhydrite) (25.50). }\end{array}$ & $\begin{array}{l}\text {-Zinc oxide (zincite) (36.27). } \\
\text {-Magnesium oxide (periclase) (42.88). } \\
\text {-Calcium sulfate (anhydrite) (25.41). }\end{array}$ \\
\hline 77 & $\begin{array}{l}\text {-Lead sulfate (anglesite) (29.68). } \\
\text {-Silicon oxide (coesite) (28.93). } \\
\text {-Calcium phosphate hydroxide hydrate } \\
\text { (brushite) (11.62). } \\
\text {-Magnesium hydroxide (brucite) (18.60). } \\
\text {-Magnesium phosphate hydrogen hydrate } \\
\text { (newberyite) (14.72). }\end{array}$ & $\begin{array}{l}\text {-Copper oxide (tenorite) (35.44). } \\
\text {-Magnesium oxide (periclase) (42.91). } \\
\text {-Calcium sulfate (anhydrite) (25.46). } \\
\text {-Calcium magnesium carbonate (calcite) (29.73). } \\
\text {-Calcium iron silicate }(30.94) \text {. } \\
\text {-Silicon oxide (coesite) (29.08). }\end{array}$ & $\begin{array}{l}\text {-Zinc oxide (zincite) (36.26). } \\
\text {-Magnesium oxide (periclase) (42.93). } \\
\text {-Calcium sulfate (anhydrite) (25.468). }\end{array}$ \\
\hline 114 & $\begin{array}{l}\text { - Lead sulfate (anglesite) (29.68). } \\
\text {-Silicon oxide (coesite) (29.18). } \\
\text {-Calcium phosphate hydroxide hydrate } \\
\text { (brushite) (11.60). } \\
\text {-Magnesium hydroxide (brucite) (38.08). } \\
\text { - Magnesium phosphate hydrogen hydrate } \\
\text { (newberyite) (14.72). } \\
\text {-Sodium calcium sulfate hydrate (bassanite) } \\
(31.76) .\end{array}$ & $\begin{array}{l}\text {-Copper oxide (tenorite) (38.75). } \\
\text {-Calcium sulfate (anhydrite) (25.50). } \\
\text {-Calcium magnesium carbonate (calcite) (29.76). } \\
\text {-Calcium iron silicate (30.94). } \\
\text {-Silicon oxide (coesite) (29.08). } \\
\text {-Calcium hydrogen phosphate hydrate (brushite) } \\
\text { (11.65). } \\
\text {-Magnesium phosphate hydrate (newberyite) } \\
(25.80) \text {. }\end{array}$ & $\begin{array}{l}\text {-Zinc oxide (zincite) (36.36). } \\
\text {-Magnesium oxide (periclase) (42.92). } \\
\text {-Calcium sulfate (anhydrite) (25.50). } \\
\text {-Calcium sulfate hydrate (bassanite) } \\
\text { (29.76). } \\
\text {-Magnesium phosphate hydrate } \\
\text { (cattiite) (31.19). }\end{array}$ \\
\hline
\end{tabular}


TABLE III: Mineral Products Formed upon Reactions with Silica 1 for Lead Sulfate, CopPer OXide ANd Zinc Oxide (MineRAL Name AND 100\% PEAK LOCATION IN DEGREES $2 \Theta$ IN BRACKETS)

\begin{tabular}{|c|c|c|c|}
\hline Day & $\mathrm{PbSO}_{4}$ & $\mathrm{CuO}$ & $\mathrm{ZnO}$ \\
\hline 0 & $\begin{array}{l}\text {-Lead sulfate (anglesite) (29.73). } \\
\text {-Calcium carbonate (calcite) (29.36). }\end{array}$ & $\begin{array}{l}\text {-Copper oxide (tenorite) (35.47). } \\
\text {-Calcium carbonate (calcite) (29.47). }\end{array}$ & $\begin{array}{l}\text {-Zinc oxide (zincite) (36.25). } \\
\text {-Calcium carbonate (calcite) (29.41). }\end{array}$ \\
\hline 14 & $\begin{array}{l}\text { - Lead sulfate (anglesite) (32.25). } \\
\text {-Calcium carbonate (calcite) (29.47). } \\
\text {-Sodium sulfate(thenardite) }(29.706) \text {. } \\
\text { - Silicon oxide (coesite) (29.26). }\end{array}$ & $\begin{array}{l}\text {-Copper oxide (tenorite) (35.55). } \\
\text {-Calcium carbonate (calcite) (29.50). } \\
\text {-Sodium carbonate hydrate (natron) } \\
(32.32) \text {. }\end{array}$ & $\begin{array}{l}\text {-Zinc oxide (zincite) (36.43). } \\
\text {-Calcium carbonate (calcite) (29.41). }\end{array}$ \\
\hline 77 & $\begin{array}{l}\text {-Lead sulfate (anglesite) (32.25). } \\
\text {-Calcium carbonate (calcite) (29.47). } \\
\text {-Sodium sulfate (thenardite) (29.706). } \\
\text {-Silicon oxide (coesite) (29.26). } \\
\text {-Calcium sulfate hydrate (gypsum) (20.73). } \\
\text {-Calcium hydroxide (portlandite) (34.10). }\end{array}$ & $\begin{array}{l}\text {-Copper oxide (tenorite) (35.55). } \\
\text {-Calcium carbonate (calcite) (29.39). } \\
\text {-Sodium carbonate hydrate (natron) } \\
(16.50) \text {. } \\
\text {-Silicon oxide (cristobalite) (22.26). }\end{array}$ & $\begin{array}{l}\text {-Zinc oxide (zincite) (36.18). } \\
\text {-Calcium carbonate (calcite) (29.41). }\end{array}$ \\
\hline 114 & $\begin{array}{l}\text {-Lead sulfate (anglesite) (32.10). } \\
\text {-Lead carbonate (cerrusite) (24.92). } \\
\text {-Calcium carbonate (calcite) (29.41). } \\
\text {-Sodium sulfate } \\
\text { (thenardite) (32.25). } \\
\text {-Calcium sulfate hydrate (gypsum) (20.77). } \\
\text {-Calcium hydroxide (portlandite) }(34.10) \text {. } \\
\text {-Calcium phosphate hydroxide hydrate (brushite) (11.60). } \\
\text {-Lead sulfate carbonate hydroxide (leadhillite) (24.93). }\end{array}$ & $\begin{array}{l}\text {-Copper oxide (tenorite) (35.56). } \\
\text {-Calcium carbonate (calcite) (29.52). } \\
\text {-Sodium carbonate hydrate (natron) } \\
\text { (16.50). } \\
\text {-Silicon oxide (cristobalite) (22.26). } \\
\text {-Calcium silicate hydroxide } \\
\text { (tobermorite) (29.47). } \\
\text {-Calcium magnesium phosphate } \\
\text { hydrate (mouetite) (26.59). }\end{array}$ & $\begin{array}{l}\text {-Zinc oxide (zincite) (36.10). } \\
\text {-Calcium carbonate (calcite) (29.37). }\end{array}$ \\
\hline
\end{tabular}

Pre-treatment analyses of $\mathrm{ZnO}$ systems revealed that the mineral composition of specimens consisted of $70 \mathrm{wt} \%$ zincite (zinc oxide), and calcite and anhydrite accounted for $30 \mathrm{wt} \%$ in the orthophosphate systems. Pre-treatment analyses of $\mathrm{ZnO}$ specimens before treatment with silica 1 and 2 revealed the mineral composition as $70 \mathrm{wt} \%$ zincite and 30 $\mathrm{wt} \%$ calcite. In the silica-orthophosphate mix systems, semi-quantitative analyses on day 0 indicated that the samples consisted of approximately $70 \mathrm{wt} \%$ zincite with the remainder of the specimens being comprised of periclase and anhydrite minerals.

After treatment, distinct changes in the mineral composition of all analyzed specimens were observed. Although several minerals formed within 14 days of treatment, the majority of minerals formed between days 14 and 114. A high level of consistency within the results of duplicate systems was achieved during pre and post treatment analyses in all systems. The most evident changes occurred in the $\mathrm{PbSO}_{4}$ and $\mathrm{CuO}$ treated systems. Tables II-V summarize the predominant mineral products which formed over the 114 day study period and identifies their angular maximum intensity peak location.

The results from XRD analyses of $\mathrm{PbSO}_{4}, \mathrm{CuO}$ and $\mathrm{ZnO}$ specimens treated with orthophosphate are in Table II. Mineral formation as a result of treatment with orthophosphate was observed in $\mathrm{PbSO}_{4}$ and $\mathrm{CuO}$ systems within 14 days of treatment and appear to have remained stable over the 114 day experimental period. Mineral formation in $\mathrm{ZnO}$ systems treated with orthophosphate was slower, but changes in the mineral composition of $\mathrm{ZnO}$ specimens were still detected by XRD before the end of the study period.

In $\mathrm{PbSO}_{4}$ systems, the predominant minerals formed upon reaction with orthophosphate included coesite, brushite, brucite, newberyite and bassanite. In $\mathrm{CuO}$ systems, anhydrite, calcium iron silicates, coesite, brushite and newberyite formed. Although mineral formation in $\mathrm{ZnO}$ systems was slower and less pronounced than in $\mathrm{PbSO}_{4}$ and $\mathrm{CuO}$ systems, bassanite and cattiite formed between days 77 and 114 .
Mineral formation upon reaction between $\mathrm{PbSO}_{4}, \mathrm{CuO}$ and $\mathrm{ZnO}$ systems with silica 1 treatment was more rapid and prominent in $\mathrm{PbSO}_{4}$ systems than $\mathrm{CuO}$ and $\mathrm{ZnO}$ treated systems. Table III presents the results from XRD analyses and demonstrates that the predominant new minerals identified upon treatment with silica 1 in $\mathrm{PbSO}_{4}$ systems were thenardite, cerrusite, coesite, gypsum, portlandite, brushite and leadhillite. Of further significance is the distinct decline in the intensity of anglesite peaks, with the complete disappearance of anglesite peaks at $22,27,36,42,44,54,68$, 78,83 and $86^{\circ} 2 \Theta$. Natron, cristobalite, tobermorite and mouetite formed in $\mathrm{CuO}$ systems treated with silica 1 . Alternatively, no new mineral products were detected by $\mathrm{XRD}$ upon reaction between $\mathrm{ZnO}$ and the silica 1 treatment; however, the intensity of all zincite peaks detected by XRD declined significantly.

Substantial changes to the mineral composition of all specimens treated with silica 2 occurred within 14 days of treatment. By day 114, thenardite, gypsum, coesite, lead silicates and bearthite formed in $\mathrm{PbSO}_{4}$ treated systems. The intensity of anglesite peaks generally declined over time and all anglesite peaks detected before treatment between $73-90^{\circ}$ disappeared by day 114 . In $\mathrm{CuO}$ treated systems, carnegiete, bohmite and calcium magnesium silicate minerals formed. Interestingly, the $\mathrm{ZnO}$ systems treated with silica 2 demonstrated the largest growth of new minerals of any $\mathrm{ZnO}$ treated system. Unidentified zeolites, monohydrocalcite, chiral zincophosphate and hopeite all formed within 114 days in the $\mathrm{ZnO}$ silica 2 treated systems (Table IV).

Table $\mathrm{V}$ includes the results from $\mathrm{PbSO}_{4}, \mathrm{CuO}$ and $\mathrm{ZnO}$ systems treated with the silica-orthophosphate mix treatment. XRD analyses detected the formation of thenardite, coesite, brushite, hydroxylapatite and spurrite in the $\mathrm{PbSO}_{4}$ systems treated with the silica-orthophosphate mix treatment. Further, anglesite peaks at 22, 24, 26, 28, 29, 37 and $78^{\circ}$ disappeared in $\mathrm{PbSO}_{4}$ systems by day 114 . In $\mathrm{CuO}$ systems, thenardite, and natrolite formed, while zeolite and anhydrite formed in $\mathrm{ZnO}$ systems treated with the silica-orthophosphate mix treatment. 
TABLE IV: Mineral Products Formed upon Reactions with Silica 2 for Lead Sulfate, Copper Oxide ANd Zinc Oxide (Mineral NAME AND $100 \%$ PEAK LOCATION IN DEGREES $2 \Theta$ IN BRACKETS)

\begin{tabular}{|c|c|c|c|}
\hline Day & $\mathrm{PbSO}_{4}$ & $\mathrm{CuO}$ & $\mathrm{ZnO}$ \\
\hline 0 & $\begin{array}{l}\text {-Lead sulfate (anglesite) (29.73). } \\
\text {-Calcium carbonate (calcite) (29.47). }\end{array}$ & $\begin{array}{l}\text {-Copper oxide (tenorite) (35.54). } \\
\text {-Calcium carbonate (calcite) (29.40). }\end{array}$ & $\begin{array}{l}\text {-Zinc oxide (zincite) (36.26). } \\
\text {-Calcium carbonate (calcite) (29.40). }\end{array}$ \\
\hline 14 & $\begin{array}{l}\text {-Lead sulfate (anglesite) (29.68). } \\
\text {-Silicon oxide (coesite) (29.41). } \\
\text {-Zeolite (13.55). } \\
\text {-Calcium silicate (32.79). } \\
\text {-Calcium aluminum silicate hydroxide } \\
\text { (clinozoisite) (30.88). }\end{array}$ & $\begin{array}{l}\text {-Copper oxide (tenorite) (35.54). } \\
\text {-Calcium carbonate (calcite) (29.47). }\end{array}$ & $\begin{array}{l}\text {-Zinc oxide (zincite) (36.27). } \\
\text {-Calcium carbonate (calcite) (29.45). } \\
\text {-Sodium zinc phosphate hydrate (chiral } \\
\text { zincophosphate) (11.37). } \\
\text {-Calcium aluminum silicate (cristobalite) (22.16). }\end{array}$ \\
\hline 77 & $\begin{array}{l}\text {-Lead sulfate (anglesite) (29.37) } \\
\text {-Sodium sulfate (thenardite) (32.14). } \\
\text {-Calcium sulfate (gypsum) (20.73). } \\
\text {-Silicon oxide (coesite) (29.35). } \\
\text {-Sodium aluminum silicate (albite) (27.85). }\end{array}$ & $\begin{array}{l}\text {-Copper oxide (tenorite) (35.54). } \\
\text {-Calcium carbonate (calcite) (29.37). } \\
\text {-Aluminum oxide hydroxide (bohmite) } \\
(14.49) \text {. } \\
\text {-Sodium aluminum oxide silicate (carnegiete) } \\
(20.81) \text {. } \\
\text {-Calcium iron silicate (ferrobustamite) } \\
(30.37) .\end{array}$ & $\begin{array}{l}\text {-Zinc oxide (zincite) (36.09). } \\
\text {-Calcium carbonate (calcite) (29.37). } \\
\text {-Silicon dioxide (zeolite) (11.26). } \\
\text {-Sodium zinc phosphate hydrate (chiral } \\
\text { zincophosphate) } \\
\text { (11.37). } \\
\text {-Sodium aluminum silicate hydrate (24.61). }\end{array}$ \\
\hline
\end{tabular}

\section{DISCUSSION}

The primary objectives of this research were i) to characterize the mineral products formed upon treatment of $\mathrm{PbSO}_{4}, \mathrm{CuO}$ and $\mathrm{ZnO}$ with orthophosphate, silica or a silica-orthophosphate mix treatment(s), and ii) to determine whether the mineral products formed upon treatment are suitably rapid and stable for the prevention of contaminant migration.

The results obtained from $\mathrm{PbSO}_{4}, \mathrm{CuO}$ and $\mathrm{ZnO}$ systems treated with orthophosphate display a high level of consistency with results from laboratory trials [5], [12], [23] which investigated the efficacy of orthophosphate treatments at immobilizing metal contaminants under cold conditions and examined the effects of freeze-thaw cycling on mineral stability. The orthophosphate treatment applied in this study had a detectable impact on all systems, but was most effective for $\mathrm{PbSO}_{4}$. In these systems all of the treatment reagents were consumed or formed new products over the 114 day study period. This is evident by the presence of phosphate being detected by XRD only in the mineral forms of brushite and newberyite. Orthophosphate was also effective for $\mathrm{CuO}$, with new mineral products being formed within 14 days of treatment and remaining stable over the 114 day study.

Treatment of $\mathrm{ZnO}$ with orthophosphate was less effective; however, new mineral products including bassanite and cattiite formed between days 77 and 114 (Table II). Although the primary contaminant phases anglesite, tenorite and zincite were still detectable by XRD in all systems treated with orthophosphate at the end of the study period, the clear reduction in the intensity of anglesite, tenorite and zincite peaks and formation of new, stable minerals including anhydrite, coesite, cattiite, bassanite, brushite and brucite indicates the potential of this treatment at metal contaminated sites in cold regions [5], [11], [12], [18]. However, there are two significant disadvantages surrounding this treatment strategy. Firstly, orthophosphate treatments have been found to mobilize metals and metalloids including arsenic [24], and secondly, over-dosage can lead to eutrophication. These represent important environmental risk considerations which must be addressed prior to on-site or in-situ application of this treatment.

Hydroxides, calcium silicates and metal silicate minerals form upon reaction between metals with silica [16], [20], [21] for the purposes of environmental remediation. This is consistent with the results of this study. XRD analyses identified hydroxides, calcium silicates and metal silicates in both silica 1 and 2 treated systems. Of the silica treated systems, silica 2 was more effective at immobilizing metals in all systems. Although several stable minerals also formed upon treatment with silica 1 (Table III), a larger range of stable mineral products formed upon treatment with silica 2 (Table IV). This is most evident in $\mathrm{ZnO}$ treated systems, where reactions between $\mathrm{ZnO}$ and silica 2 treatment produced more stable minerals than any other treatment (Table IV). The increased immobilization potential and efficiency of silica 2 demonstrated the effect of supplying orthophosphoric acid to the treated material directly after the application of a silica solution. Orthophosphoric acid improved immobilization efficacy in two ways. Firstly, it facilitated direct reactions between phosphorus and metals which prompts the formation of new minerals, similar to the orthophosphate treatment. Secondly, the application of orthophosphoric acid decreases the $\mathrm{pH}$ of the treated material which enhanced the gelation reactions responsible for the polymerization of soluble silicates, thereby initiating faster and more complete formation of insoluble silicate minerals [16]. A further advantage of applying orthophosphoric acid directly after a silica treatment is the increased probability of producing a $\mathrm{pH}$ neutral post-treatment soil material.

The silica-orthophosphate mix also was effective at immobilizing metals, and unsurprisingly several minerals that formed in the orthophosphate and silica treated systems (including thenardite, coesite, natrolite, brushite and 
anhydrite) were detected in the specimens treated with the silica-orthophosphate mix treatment.

The formation of measureable quantities of new mineral species, changes to the mineral composition of analyzed specimens and reductions in the intensity of contaminant peaks was observed in all systems, over the 114 day study period. The results in this study are consistent with recent literature reviews [16], [17] and experimental studies [5], [12], [18], [19]. Although contaminant species remained present in all systems at the end of the study period, by day 114 the presence of anglesite in $\mathrm{PbSO}_{4}$ systems was reduced to trace levels in all treated systems, and $\mathrm{CuO}$ systems appeared to have reached equilibrium by the end of the study period. Immobilization of $\mathrm{ZnO}$ was slower and less complete; however, the silica 2 and silica-orthophosphate mix treatments demonstrate strong potential for $\mathrm{ZnO}$ immobilization in cold regions.

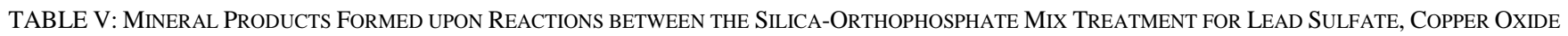
AND ZINC OXIDE (MINERAL NAME AND 100\% PEAK LOCATION IN DEGREES $2 \Theta$ IN BRACKETS)

\begin{tabular}{|c|c|c|c|}
\hline Day & $\overline{\mathrm{PbSO}_{4}}$ & $\overline{\mathrm{CuO}}$ & $\mathrm{ZnO}$ \\
\hline 0 & $\begin{array}{l}\text {-Lead sulfate (anglesite) (29.93). } \\
\text {-Magnesium oxide (periclase) (42.92). }\end{array}$ & $\begin{array}{l}\text {-Copper oxide (tenorite) (35.54). } \\
\text {-Magnesium oxide (periclase) (42.94). } \\
\text {-Calcium sulfate (anhydrite) (25.46). } \\
\text {-Calcium magnesium carbonate (calcite) (29.73). }\end{array}$ & $\begin{array}{l}\text {-Zinc oxide (zincite) (36.26). } \\
\text {-Magnesium oxide (periclase) } \\
\text { (42.89). } \\
\text {-Calcium sulfate (anhydrite) (25.44). }\end{array}$ \\
\hline 14 & $\begin{array}{l}\text {-Lead sulfate (anglesite) (29.71). } \\
\text {-Magnesium oxide (42.86). } \\
\text {-Sodium sulfate (thenardite) (32.09). } \\
\text {-Calcium lead phosphate hydroxide } \\
\text { (hydroxylapatite) (30.72). }\end{array}$ & $\begin{array}{l}\text {-Copper oxide (tenorite) (35.49). } \\
\text {-Magnesium oxide (periclase) (42.94). } \\
\text {-Calcium sulfate (anhydrite) (25.50). }\end{array}$ & $\begin{array}{l}\text {-Zinc oxide (zincite) (36.27). } \\
\text {-Magnesium oxide (periclase) } \\
\text { (42.91). } \\
\text {-Calcium sulfate (anhydrite) (25.49). }\end{array}$ \\
\hline 77 & $\begin{array}{l}\text { - Lead sulfate (anglesite) (29.68). } \\
\text {-Sodium sulfate (thenardite) (32.09). } \\
\text {-Silicon oxide (coesite) (28.93). } \\
\text {-Calcium phosphate hydroxide hydrate (brushite) } \\
\text { (11.60). } \\
\text { - Calcium lead phosphate hydroxide } \\
\text { (hydroxylapatite) (30.66). } \\
\text {-Calcium carbonate silicate (spurrite) (33.14). }\end{array}$ & $\begin{array}{l}\text {-Copper oxide (tenorite) (38.74). } \\
\text {-Sodium sulfate (thenardite) (32.25). } \\
\text {-Magnesium oxide (periclase) (42.89). } \\
\text {-Zeolite }(6.12) \text {. -Silicon oxide }(20.41) \text {. }\end{array}$ & $\begin{array}{l}\text {-Zinc oxide (zincite) (36.27). } \\
\text {-Magnesium oxide (periclase) } \\
\text { (42.89). } \\
\text {-Calcium sulfate (anhydrite) (25.44). } \\
\text {-Sodium sulfate (thenardite) (32.25). }\end{array}$ \\
\hline 114 & $\begin{array}{l}\text {-Lead sulfate (anglesite) (29.68). } \\
\text {-Sodium sulfate (thenardite) (32.10). } \\
\text {-Calcium phosphate hydroxide hydrate (brushite) } \\
\text { (11.60). } \\
\text { - Calcium lead phosphate hydroxide } \\
\text { (hydroxylapatite) (30.60). } \\
\text {-Calcium carbonate silicate (spurrite) (33.14). }\end{array}$ & $\begin{array}{l}\text {-Copper oxide (tenorite) }(35.54) \text {. } \\
\text {-Sodium sulfate (thenardite) }(32.55) \text {. } \\
\text {-Zeolite }(6.16) \text {. } \\
\text {-Sodium aluminum silicate hydrate (natrolite) } \\
(31.77) \text {. }\end{array}$ & $\begin{array}{l}\text { - Zinc oxide (zincite) (36.27). } \\
\text {-Magnesium oxide (periclase) } \\
\text { (42.94). } \\
\text {-Calcium sulfate (anhydrite) (25.54). } \\
\text {-Sodium sulfate (thenardite) (32.19). }\end{array}$ \\
\hline
\end{tabular}

Several factors can account for the variation in treatment performance for different metals, some of which have been discussed in earlier studies [5]. The formation of copper phases is typically unaffected by low temperatures; however, reaction kinetics in cold conditions are reduced and can result in slower formation of certain minerals. As such, it is possible that a longer-term study of a similar design might detect new mineral phases not identified in this study. Another important consideration surrounding the treatment of lead, particularly with orthophosphate is the solubility of reaction products formed during treatment. In many cases the products produced by treatment of lead with orthophosphate under cold conditions are more soluble, less complete and less stable than those produced upon reaction between orthophosphate and other metals e.g. copper, under cold conditions [5]. The treatments were less effective at immobilizing $\mathrm{ZnO}$, possibly due to the lower solubility of zinc leading to the formation of fewer, less soluble mineral products [5].

Other factors independent of the type of metals requiring treatment may also affect the performance of chemical treatments. Orthophosphate in the form of triple super phosphate is naturally acidic and requires $\mathrm{pH}$ buffering in acidic soils prior to treatment, to prevent acidification and mobilization of metals and metalloids. With respect to silica treatments, the solubility of silica dramatically decreases in environments where $\mathrm{pH}$ is below 7-8. This requires the development of highly alkaline treatment solutions to ensure that silica remains in solution long enough to react with contaminants prior to precipitation [16]. Salinity may also affect mineral production and the stability of minerals, for example the stability of bassanite increases with increasing salinity [25]. The reverse effect is also possible for other mineral products and has the potential to reduce the effectiveness of remediation [25]. Temperature also plays an important role by reducing the speed of reaction kinetics, but can also change the mineral composition of treated materials, for example the more stable thenardite transforms into mirabilite at lower temperatures $\left(-8.2-1.2^{\circ} \mathrm{C}\right)$ [12], [26]-[28]. This also highlights the importance of natural freeze-thaw cycling in cold environments as mineral products can be altered by temperature or as a result of desiccation upon thawing [12], [23].

Although this study provides new information supporting the application of orthophosphate, silica and silica-orthophosphate mix treatments in cold regions, it is limited in several ways. Firstly, the relatively short time frame of the experiment (114 days) does not provide for a detailed understanding of the longer term stability of these reactant products, nor does it an allow for a characterization of mineral products which form over longer times. This is particularly relevant to these results as the entire experiment was undertaken under cold conditions which reduces the speed of reaction kinetics significantly. Further, this study 
did not examine the effects of natural freeze-thaw cycling. Freezing and thawing might change the mineral products formed, or result in hydration and dehydration of minerals, which might affect the stability of reaction products formed during treatment [12], [23]. This also influences the long-term efficacy of in-situ application of such treatments and represents an important consideration when applying this technique in cold regions. Another limitation of this study is that it assessed only three metal species $\left(\mathrm{PbSO}_{4}, \mathrm{CuO}\right.$ and $\mathrm{ZnO}$ ), and an assessment on a wider range of contaminants would be beneficial and provide a better indication of the overall performance of this technology for management of metal contaminated sites.

\section{CONCLUSION}

This study characterized the mineral products formed upon reactions between $\mathrm{PbSO}_{4}, \mathrm{CuO}$ and $\mathrm{ZnO}$ with orthophosphate, silica and an orthophosphate-silica mix treatment under cold conditions. Detectable minerals formed within all systems and these remained stable over the study period indicating that these treatments have the potential to immobilize metals and prevent contaminant migration at contaminated sites in cold regions. However, further studies are required before the safety and efficacy of the treatments trialed in this experiment can be considered safe for on-site or in-situ application.

This study examined the performance of four treatments at immobilizing metals in reagent grade chemical systems in order to characterize mineralogy. In natural soil environments, porosity, grain and soil pore size, organic content and competing ions all affect treatment performance. Therefore, studies which consider the impact of these natural factors should be undertaken before this technology is implemented on-site or in-situ at metal contaminated sites. To achieve this, long-term batch and field based experiments trialing additional treatment compositions on a wider range of materials and soil types are required. Such experiments should assess treatment performance by measuring the total concentrations of metals in soil and leachate and should monitor soil $\mathrm{pH}$, salinity and oxidation-reduction state.

\section{ACKNOWLEDGEMENT}

D. Camenzuli thanks Russell Field for training on X-ray diffractometry techniques and analyses and assistance in the laboratory, and Marek Roullion and the reviewers for feedback on the manuscript.

\section{REFERENCES}

[1] J. S. Poland, M. J. Riddle, and B. A. Zeeb, "Contaminants in the Arctic and the Antarctic: A comparison of sources, impacts, and remediation options," Polar Record, vol. 39, pp. 369-383, 2003.

[2] D. M. Filler, C. M Reynolds, I. Snape, A. J. Daugulis, D. L. Barnes, and P. J. Williams, "Advances in engineered remediation for use in the Arctic and Antarctica," Polar Record, vol. 42, pp. 111-120, 2006.

[3] D. Camenzuli, B. L. Freidman, T. M Statham, K. A. Mumford, and D. B. Gore, "On-site and in-situ remediation technologies applicable to metal-contaminated sites in Antarctica and the Arctic: a review," Polar Research, vol. 33, p. 21522, 2014.

[4] R. Bargagli, Antarctic Ecosystems: Environmental Contamination, Climate Change, and Human Impact, Ecological Studies, New York: Springer-Verlag, 2005, vol. 175.
[5] D. A. White, E. G. Hafsteinsdóttir, D. B. Gore, and G. Thorogood "Formation and stability of $\mathrm{Pb}-, \mathrm{Zn}-$ and $\mathrm{Cu}-\mathrm{PO}_{4}$ phases at low temperatures: implications for heavy metal fixation in polar environments," Environmental Pollution, vol. 161, pp. 143-153, 2011.

[6] P. P. Deprez, M. Arens, and H. Locher, "Identification and assessment of contaminated sites at Casey Station, Wilkes Land, Antarctica," Polar Record, vol. 35, pp. 299-316, 1999.

[7] L. D. Dyke, "Contaminant migration through the permafrost active layer, Mackenzie Delta Area, Northwest Territories, Canada," Polar Record, vol. 37, pp. 215-228, 2001.

[8] D. W. Schindler and P. G. Lee, "Comprehensive conservation planning to protect biodiversity and ecosystem services in Canadian boreal regions under a warming climate and increasing exploitation," Biological Conservation, vol. 143, pp. 1571-1586, 2010.

[9] Q. Y. Ma, S. J. Traina, T. J. Logan, and J. A. Ryan, "In-situ lead immobilization by apatite". Environmental Science and Technology, vol. 27, pp. 1803-1810, 1993.

[10] X. Cao, L. Q. Ma, S. P. Singh, and Q. Zhou, "Phosphate-induced lead immobilization from different lead minerals in soils under varying $\mathrm{pH}$ conditions," Environmental Pollution, vol. 152, pp. 184-192, 2008.

[11] E. G. Hafsteinsdóttir, "Fixation of metals and metalloids of environmental concern in areas of freezing ground using orthophosphate,” Ph.D. dissertation, Dept. Environ. Sci., Macquarie Univ., Sydney, NSW, 2012.

[12] E. G. Hafsteinsdóttir, D. A. White, D. B. Gore, and S. C. Stark, "Products and stability of phosphate reactions with lead under freeze-thaw cycling in simple systems," Environmental Pollution, vol. 159, pp. 3496-3503, 2011.

[13] N. T. Basta, and S. L. McGowen, "Evaluation of chemical immobilization treatments for reducing heavy metal transport in a smelter-contaminated soil," Environmental Pollution, vol. 127, pp. 73-82, 2004

[14] G. Guo, L. Q. Zhou, and L. Q. Ma, “Availability and assessment of fixing additives for the in situ remediation of heavy metal contaminated soils: A review," Environmental Monitoring and Assessment, vol. 116, pp. 513-528, 2006.

[15] L. N. Shi, X. Zhang, and Z. L. Chen, "Removal of chromium (VI) from wastewater using bentonite-supported nanoscale zero-valent iron,' Water Research, vol. 45, pp. 886-892, 2011.

[16] D. Camenzuli and D. B. Gore, "Immobilization and encapsulation of contaminants using silica treatments: a review," Remediation, vol. 24, 49-67, 2013.

[17] E. G. Hafsteinsdóttir, D. Camenzuli, A. L. Faunce, J. Walworth, and D B. Gore, Fixation of Metals and Metalloids by Orthophosphate, 2014.

[18] D. Camenzuli, D. B. Gore, and S. C. Stark, "Immobilisation of metals in contaminated landfill material using orthophosphate and silica amendments: a pilot study," in Proc. the $6^{\text {th }}$ International Conference on Environmental Pollution Remediation, Prague, August 2014.

[19] M. A. Abdel-Hamid, M. M. Kamel, E. M. M. Moussa, and H. A Rafaie, "In-situ immobilization remediation of soils polluted with lead, cadmium and nickel," Global Journal of Environmental Research, vol. 6, pp. 1-10, 2012.

[20] P. Mitchell, J. T. Rybock, and A. L. Anderson, "Silica micro encapsulation: An innovative commercial technology for the treatment of metal and radionuclide contamination in water and soil," in Proc. the 6th Symposium on Environmental Issues and Waste Management in Energy and Mineral Production, Calgary, Canada, 2000.

[21] P. Mitchell, A. Anderson, and C. Potter, "Protection of ecosystem and human health via silica micro encapsulation of heavy metals," in Proc. 7th International Mine Water Association Congress, Ustron, Poland, 2000, pp. 146-156.

[22] G. M. Naja and B. Volesky, "Treatment of metal-bearing effluents: Removal and recovery," in Heavy Metals in the Environment: Handbook of Environmental Engineering, L. K. Wang, J. P. Chen, Y. T. Hung and N. K. Shammas, Eds. 2009, pp. 247-292.

[23] E. G. Hafsteinsdóttir, D. A. White, and D. B. Gore, "Effects of freeze-thaw cycling on metal-phosphate formation and stability in single and multi-metal systems," Environmental Pollution, vol. 175, pp. 168-177, 2013.

[24] F. J. Peryea, "Phosphate-induced release of arsenic from soils contaminated with lead arsenate," Soil Science Society of America Journal, vol. 55, pp. 1301-1306, 1991.

[25] M. Ossorio, A. E.van Driessche, P. Perez, and J. M. Garcia-Ruiz. (July 2013). Precipitation process and phase stability of calcium sulfate; the role of temperature, salinity and time of reaction. Science 24. [Online]. Available: http://science24.com/paper/29774

[26] H. E. Doner and W. C. Lynn, "Carbonate, halide, sulfate, and sulfide minerals," in Minerals in Soil Environments, J. B. Dixon and S. B. Weed, Eds. Madison: Soil Science Society of America, pp. 279-330. 
[27] G. M. Marion, R. E. Farren, and A. J. Komrowski, "Alternative pathways for seawater freezing," Cold Regions Science and Technology, vol. 29, pp. 259-266, 1999.

[28] J. K. Warren, "Evaporites through time: tectonic, climatic and eustatic controls in marine and nonmarine deposits," Earth Science Reviews, vol. 98 , pp. 143-153, 2010.

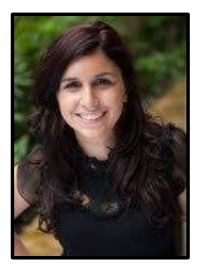

Danielle Camenzuli was born in Sydney, Australia. Ms. Camenzuli completed her bachelor degree of environmental science (Hons.) at Macquarie University in Sydney in 2011 and will complete her PhD degree in environmental engineering at Macquarie University in 2015.

Her research portfolio and previous employment has provided her with experience in environmental impact assessment, environmental management, contaminated lands, project management and environmental education. During her career period, she has been employed in the private sector and public sector. She has published six peer-reviewed scientific articles in journals including Environmental Pollution, Antarctic Science, Polar Research, Remediation and Polar Record. Her current research interests surround the development and application of innovative technologies for the management of metal and hydrocarbon contaminated land. 